\title{
A STUDY OF FOURTEEN INTERPRETATIONS FOR Human Reproductive Cloning and Violating Man's Dignity
}

\author{
Morteza Agha-Mohammadi \\ Al-Mustafa International University, Qom, I. R. Iran
}

\begin{abstract}
Since the time the theory of practicing human reproductive cloning was felt to be close to turn into reality, there were many objections against it. These objections were from different scientific, jurisprudential, ethical, or religious perspectives. One of the ethical objections strongly asserted against this type of cloning by different parties was its violating human dignity. Since in many cases it is not specified what is meant by this claim, this article suggests fourteen interpretations for it and struggles to evaluate and analyze each of them. Altering the specific way of procreation, changing genetic structure, using man as a bank of organs, choosing man's attributes, turning him/her into a product, having only one genetic parent, turning man into a laboratory mouse, imposing one's identity on another person, hurting collective dignity of all humanity, ignoring man's freedom and the right to choose, misusing cloned people, negating the principle of end, exploiting women, increasing illicit sexual relations, are all different interpretations of the claim which are going to be studied.
\end{abstract}

Keywords: Human reproductive cloning, violation, man's dignity, fourteen interpretations

\section{Definition of Cloning}

The word "clone" is used in many different contexts in biological research, but in its simplest and strict sense, it refers to a precise genetic copy of a molecule, cell, plant, animal, or human being. Cloning is to produce a copy of one thing (Ma 2004: 29). There are three types of cloning: 
A. DNA Cloning that is mainly used to produce replicas of the same gene, in turn, allowing scientists to thoroughly study the genome.

B. Therapeutic Cloning that is the idea of using human stem cells in order to study human development and treat disease. The problem with therapeutic cloning is that in order to perform a study on development or disease a human embryo is used and, more often than not, destroyed. (Lopez 2004: 2-3).

C. Reproductive Cloning, which is a technology used to produce copies of other animals.

\section{Brief History of Cloning}

The possibility of reversing the process of cell differentiation and, hence, of using more developed cells for nuclear transfer, was described in 1938 by Hans Spemann (Spemann 1938: 211). The first success in mammalian nuclear transfer used embryonic cells as donors and was reported by Illmensee and Hoppe (McGrath \& Solter 1984: 179-183). There were many struggles in this regard till finally Ian Wilmut came to describe the successful application of almost exactly the same method, but using the nuclei of somatic cells from an adult mammal, to create Dolly the sheep (Vajta \& Gjerris 2006: 211).

\section{Reactions to Possible Human Reproductive Cloning}

This raised worries around the world about possible cloning of a human being. There were many struggles against the issue. The Universal declaration on the Human Genome and Human Rights of the United Nations, 1997 (UDHGHR) emphasizes the need to fully respect human dignity, freedom, and human rights. Article 11 states:

Practices which are contrary to human dignity, such as reproductive cloning of human beings, shall not be permitted. (Shalev 2002: 137)

A worldwide ban on Cloning Human Beings was proposed by France and Germany to the UN in 2001 and it has been effective since September 2006 (Kfoury 2007: 113). The World Health organization (WHO) declared:

Cloning for the replication of human individuals is ethically unacceptable and contrary to human dignity and integrity. (Birnbacher 2005: 50)

\section{Violation of Man's Dignity}

From the religious side, there were strong objections against the issue, especially from the Christians and Muslims, considering it against their laws and ethics. They suggest different arguments against reproductive cloning of 
a human being. One of their strongest objections is to call it a violation of man's dignity. In Islamic ethics, as well as Islamic jurisprudence, man's dignity is an important principle. Other religions also consider the dignity of man to be the manifestation of the divine will; therefore, no one can negate it from human beings (Mowahhed 2002: 423). According to the head of the Muslim World League, human reproductive cloning is a big threat against human dignity (al-Qaradawi, internet). Mohaghegh Damad a Shia scholar says:

Any attempt by a person or others to violate man's dignity will be morally and juristically forbidden. Therefore, man cannot morally permit genetic studies and research on his/her genome to be done in a way that hurts his/ her dignity. (Mohaghegh Damad 2007: 29)

The opponents of cloning believe that a cloned man is deprived of this respect and dignity, because those who are cloning are essentially misusing them.

In order to understand the issue better and to avoid an emotional judgment, we need to find out in which sense cloning damages a man's dignity. It is difficult to find a clear response to this question. Almost all of those writings are general and they just claim that cloning is against a man's dignity without mentioning why and how. To analyze these arguments, we will bring and analyze fourteen interpretations supporting the claim that cloning disrespects humans.

\section{Different Interpretations of This Claim}

\section{First: violating specific way of procreation}

Man's dignity is in the specific way of procreation, bearing, and delivering a baby. Therefore, any attempt to change or find other alternatives for this natural way violates man's dignity. Cloning is unacceptable because cloned children would essentially be manufactured rather than conceived, they could potentially be viewed by society as commodities and treated as less than fully human. So, according to this view, in order to safeguard human beings' dignity, reproductive cloning should not replace the natural way of procreation (al-Barzanji \& al-Adili 2001: 102).

\section{Analysis}

There are some problems with this interpretation:

A. There are many other animals having the same way of bearing and giving birth to their young as humans. So, this is not specific to man and, 
if it is the criterion for having the mentioned dignity, then the same must apply for other animals as well, while we see that God declares in the Quran that He has only favored man by this dignity (Quran 17: 70). Therefore, this interpretation does not provide the right meaning for man's dignity (Atrak 2012: 164).

B. According to this explanation, wherever procreation and bearing and delivering do not occur in the natural way, then man's dignity is violated. To accept this, we will have a problem in justifying the birth story of Jesus (Ayatee \& Ameriniya 2008: 164). Not only is the creation of Jesus not against his dignity but, on the contrary, it's a kind of privilege for him, making him so special that some came to consider him as the son of God. Also, those who are born through IVF (In Vitro Fertilization) must have lost their dignity, while the opponents of cloning permit it and they do not consider it a violation of man's dignity. Furthermore, considering those who are delivered through Cesarean section, even though the process of insemination is natural, it is not a natural way of delivering a baby, yet it is certainly not a violation of a man's dignity. Therefore, it does not seem acceptable to relate the way of man's birth to his/her dignity.

\section{Second: hurting man's genetic structure}

Man's dignity is bound to keeping his genetic structure and combination untouched. Therefore, any attempt to interfere with this genetic structure is in essence disrespect to him. Since they play with human genes in reproductive cloning, it is against his dignity and therefore forbidden (Owdatullah 2003: 136).

\section{Analysis}

The first and the most serious problem with this interpretation is that it is not universal. If any interference in a man's genes is considered to be violating his dignity, the same must be applied to other cases where there is interference in the genes, while most of the opponents accept therapeutic changes to be conducted.

\section{Third: producing man as a bank of organs}

Human cloning is intrinsically evil because it reduces human procreation to a mere manufacturing process, producing new human beings in the laboratory to predetermined specifications as if they were commodities. It shows disrespect for human life in the very act of generating it. This is espe- 
cially clear when human embryos are produced by cloning for research purposes because new human lives are generated solely in order to be destroyed. The ethicists have another worry: that a cloned man might be considered as a bank to keep organs for his/her source, i.e. they grow a cloned copy of someone to use his/her organs whenever necessary. In 1997, a universal chorus of religious naysayers offered that it would be immoral to clone whole humans to use them as organ banks (Cogan 1998: 195).

\section{Analysis}

Certainly producing a man as a bank of organs is immoral and forbidden, but we should not forget that cloning is a very expensive and time-consuming process, so very few people can afford to do that. It is much cheaper to buy organs in the black market whenever needed, rather than spending a great deal of money and waiting many years to use the organs of a cloned one. Besides, this argument is a concern about a possible misuse of technology, but it cannot reject the whole of it, i.e. by appealing to this argument, we cannot forbid a sterile couple to clone their own child.

\section{Fourth: only God can decide the attributes of man}

It can be said on behalf of the naysayers that man is created by God and $\mathrm{He}$ is the only one who has the right to make decisions for him/her and to choose his/her attributes and features, as the verse reads:

$\mathrm{He}$ it is who shapes you in the wombs as He likes; there is no god but $\mathrm{He}$, the Mighty, the Wise. (Quran 3: 6)

So it is He who fashions every individual in the womb of his/her mother. The color, height, gender, and the other characteristics of man are specified by God. Therefore, a man considers himself to be the creation of God and the outcome of His will and desire which is based on divine wisdom. So, all human beings are the same in their creation, but when someone is cloned he/she is the result of a man's decision and there is not that absolute wisdom behind whatever he/she has been given. He/she is not like others in creation. To feel that others are involved in what feature he/she has, the person will not consider himself/herself a normal person and this hurts his/her dignity.

\section{Analysis}

In the natural procreation, God's will is at the top of the chain of causes and $\mathrm{He}$ does not create without causes being involved. Inheritance, food, age of the parents, the weather, and many other elements might have their role 
in forming an individual but they do not deny the will and role of God who is at the top of the chain of causes. If a black man marries a white woman, there is a possibility of their children being white or black or a color in between. So, this is in the hand of the parents when they choose their partner to marry, while if a black father married a black woman, then the possibility for the child to be white would be almost zero. This role of the partial causes is there, as well as the divine will behind them. Therefore, the same reality exists when someone is cloned, i.e. the causes have their role, but God's will is behind them. To put a somatic cell in a nucleus-free ovule or to have sexual intercourse, both can deliver a baby by the permission of the Almighty, so the cloned baby is also the creation of God and, at the same time, the other elements might have their effect on the characteristics of the baby, the same as natural procreation.

Moreover, we have religious recommendations to follow in order to have specific characteristics in the baby, for example to have a wise or pretty child, some foods and fruits have been suggested to be eaten and also some supplications are recommended to be recited. There are also things to be avoided to safeguard the baby from specific deficiencies, while none of these are considered to be interference in the creation of God or to be playing with the child or damaging its dignity, but on the contrary, all these things are favors to the child and the same can be applied to cloning. In conclusion, these actions are not counted as interference in the destiny of the child and God's will, or at least this amount of interference does not seem to be impermissible.

The final point is that cloning does not entail making changes to the fetuses to be obligatory, i.e. they can put the somatic cell in the ovule without any genetic changes in the DNA and the ovule. The only thing that remains is that the child will be very similar to the donor of DNA, but again there does not seem to be any problem with that.

\section{Fifth: turning man into an object}

The cloned man will be underestimated to serve as a product in the hand of others and will be a property for them; therefore he/she will be subjected to their whims and wishes (Ranjbariyan \& Seyf 2009: 143). The violation of human dignity lies in the fact that the future child is made an object of the parents' wishes (Birnbacher 2005: 52).

\section{Analysis}

To say that the baby is subjected to the wishes of others is a very pessimist look at cloning. The couples can have their child through the fusion 
of the somatic cell and the ovule and then put it in the womb of a mother, while in sexual reproduction the child is born out of semen and the ovule being inseminated. They are not much different in this regard. Of course there might be cases to misuse and misbehave cloned babies, but it is not a problem with this technology itself, it is a wrong way of handling it. Besides, the same can be ascribed to IVF and genetic engineering. Also, some of the other answers suggested above can be applied here.

\section{Sixth: Having a single genetic parent}

Knowing that the child has only one genetic parent will cause humiliation for the cloned person and will damage his/her dignity.

\section{Analysis}

Why should the child feel that he/she has only one parent when the somatic cell of his father is fused with the ovule of the mother and planted in her uterus and stayed there for nine months and was breastfed by the mother after being born? Moreover, when cloning becomes an acceptable way of procreation, then it will be felt as natural as the method of sexual intercourse.

\section{Seventh: Turning man into a laboratory mouse}

Turning man into a laboratory mouse is the violation of his dignity (Khabir \& Talibi 2012: 103). Cloning is humiliating a man's dignity by practicing those experiments on him/her that are done on other animals.

Wahbah Al-Zohayli apparently believes that genetic interference with the intention of optimizing the condition of the embryo is also an example of violating its human dignity. He adds that if by doing these things, the goal is to reform and remove some serious inheritable and genetic diseases, then there would be no problem with it. But, if the purpose is promotion of a specific race or increasing the mind power and capabilities, it is not permissible, because besides changing God's creation, it is also against man's dignity (Fadhlullah et al. 1997: 126-127).

\section{Analysis}

A man has dignity, i.e. he/she should not be treated like other animals because cloning hurts this dignity of a human when they are treated like mice and rabbits. If we accept this interpretation, then any kind of research 
on men must be considered forbidden and immoral. Various medical research on rabies, radiotherapy and other achievements in the world of medicine that today are practiced on men in a large scale and are morally acceptable, have passed a testing period. During that period, the tests were not done on specific people in order to find out the results of the function of a special therapy and its possible side effects, and neither the scientists nor the patients could foresee the consequences and results of those tests. This period was a time of fear and worry of being sacrificed. So, we must consider all these tests to be immoral. From this perspective, there is no difference between the first IVF performed and cloning. In both, the technique that was tested successfully on animals was being practiced on humans for the first time without being certain about the result. We need to distinguish two things from one another: One is to ban any sort of experimental test on humans and consider it to be immoral. The other point is to struggle to find ethical codes and regulations that should be observed in these tests. The opponents of cloning have not differentiated between these two. As a matter of fact, there have been many people during the history of the world that have been used in different tests as laboratory mice. During the Second World War, thousands of people in the laboratories of prisons were subjected to different tests, to study their effects on men. Such attempts necessitated issuing some rulings for the tests to be done on humans and, finally, in the year 1974, ten articles under the name "Nuremberg code" were published. The first article emphasizes that the voluntary consent of the human subject is absolutely essential (Shuster 1997: 1437). It focuses on the consent of those people that are tested along with a complete awareness of what is to be done in any experiment to be practiced on human beings. To abandon these experiments is not reasonable. Otherwise, no tests must be done on human beings at all and even we will not be allowed to test some simple tablets for migraine headaches. So, to do these tests is not immoral in their nature. Rather what makes such experiments immoral is to deliberately keep the people who are acted as subjects, ignorant about these tests while the victims do not have any free will or autonomy to decide whether they want to participate or not. Therefore, the experts in bioethics, instead of rejecting these tests in their essence, have tried to formulate some principles to guide scientists in these experiments. The outcome of their efforts was the declaration of four main ethical codes for bioethics mentioned below: "the principle of non-maleficence" "the principle of beneficence", "the principle of justice", and "the principle of autonomy" (Eslami 2006: 21).

In brief, these principles mean that we have to treat others the same way that we expect others to treat us. This means, no one should be able to perform a test on someone except when they are well informed about the test 
and until they agree to it by their own free will. The opponents of cloning might raise their objection by saying that the problem with cloning is that you cannot ask the permission and get consent from the embryo you want to clone. It is possible he/she might not be happy with the cloning and this is his/her right to be born from a natural way, so cloning is not a just act.

It can be said that before the cloning process, the child does not technically exist, so this claim can be rejected as there is no way to ask for his/her permission, and after procreating it through cloning, asking for permission has no meaning. So, the child actually owes his/her own being and life to cloning. Imagine an infertile couple with no option of having a child except through cloning. Now, if they do not consent to cloning, is there any possibility for them to have a child from sexual intercourse?

And besides all this, there is still the fact that the same problem can be ascribed to IVF, because, in that case, it can also be said that the child has this right to be born from the natural way of intercourse. In brief, if the opponents of human reproductive cloning mean that doing any experiment on man is forbidden, then this does not go along with the other cases in which they permit experimentation. But, if they mean that experiments like cloning are to be forbidden, then they have to clarify what is the difference between cloning and other experiments and why cloning is the only one to be prohibited.

\section{Eighth: To impose one's identity on others}

Those who do cloning impose their identity or that of others on the cloned baby. So, cloning is an immoral action from this vantage point. "Consequentialist objections consider cloning to harm the child. An example is the 'life in the shadow' argument. It believes that the child will be expected to lead a life that follows in the footsteps of the older person who has the same DNA. These expectations will put pressure on the cloned children, since they are not free to follow a different path that might be more conducive to their wellbeing" (Strong 2005: 47).

\section{Analysis}

A. What is wrong with being able to choose some good attributes for a child to be good looking and handsome? A child is very likely to appreciate being cloned if he/she finds out in the future that because of cloning they were given such good attributes. When a cloned person sees that, for example, he/she has a beautiful nose and it is due to being cloned, he/she is not likely to be unhappy with it. 
B. It is not necessary to impose specific features on the baby, and cloning can be done without changing anything to the embryo, so cloning does not entail genetic changes.

C. If it is about features related to a man's personality then the fact is that the behavioral characteristics are not only received through genes; there are in fact many other elements involved in forming someone's personality such as the family, environment, society.

D. One might claim that any interference with the attributes of the person is not forbidden and that is why we see many Islamic traditions suggesting specific actions to be done or things to be eaten in order to impact the gender of the embryo or its characteristics. We can get the same results with cloning, so this can be considered moral.

\section{Ninth: Hurting collective dignity of all humanity}

Not only the dignity of individuals, but also the collective dignity of all humanity is in danger. Those who raise this argument appeal to some parts of the statement of the UNESCO: "No research on man's genome or its applications in specific; in the field of biology, genetics, and medicine is allowed to overcome man's rights, basic freedoms, and the dignity of individuals or a group of people."

By claiming the contradiction between cloning and the dignity of individuals or all humanity, the opponents of human reproductive cloning struggle to force limits and ban it on an international scale. Seemingly, the attempts done by the United Nations, UNESCO, and the World Health Organization (WHO) to limit human reproductive cloning were in this course. For example, we can refer to the universal statement of UNESCO about man's genome and human rights that abandons reproductive cloning of men due to it being against his/her dignity (Ranjbariyan \& Seyf 2009: 144).

\section{Analysis}

We see that all these claims are vague and they do not explain in what sense cloning can hurt the dignity of all humanity while its damage to individuals is not proven yet. The concept of dignity in the Quranic understanding as the greatest gift that has been bestowed only to man refers to reason and intellect that can lead him/her towards perfection. Without any doubt, the cloned man also has this very faculty and gift, so cloning is not against the dignity of man. 


\section{Tenth: Ignoring man's freedom and right to choose}

One of the differences between cloning and other fields of research on man is that research like this often does not pose a threat or risk to the subjects, but instead, for the products, i.e. the cloned babies. For these babies, this is against their primary rights, such as the right to choose. According to the article 22 of the Declaration of Helsinki, "participation by competent individuals as subjects in medical research must be voluntary. Although it may be appropriate to consult family members or community leaders, no competent individual may be enrolled in a research study unless he or she freely agrees." In article number 24 we read that in medical research involving competent human subjects, each potential subject must be adequately informed of the aims, methods, sources of funding, any possible conflicts of interest, institutional affiliations of the researcher, the anticipated benefits and potential risks of the study and the discomfort it may entail, and any other relevant aspects of the study. While in cloning, the cloned babies are deprived of this very basic right of knowing the consequences of the research on them (Noormohammadi 2005: 73).

\section{Analysis}

There are two points to be mentioned here:

A. Before the cloning process, these babies do not exist to have any right and after the cloning process the time for making a decision has passed. So, one cannot say their right has been transgressed because there are no rights for someone who does not exist. The same is with the babies who are born naturally. Before their existence, they do not have any right, so they cannot complain about their being born or being from such and such father and mother, etc. So, being born from cloning is not against the right of the babies for choosing their way of birth.

B. Another fact to bear in mind is that when choosing between existence and negation, existence has the priority, so "being" is better than "not being". Therefore, according to what we can understand from our sources, being born is more beneficial than not existing at all, be it from cloning or via natural methods.

\section{Eleventh: Misusing cloned people}

Why permit a technology that perhaps only the rich will be able to use? That can be subjected to misuse by criminal minds? (Lin, Internet) It might 
be the scientists who start the projects on cloning, but surely they are not going to handle it in the future. Rather different political issues and personal and party advantages will be involved and may take control over cloning projects. While most scientific research usually begins with the intention to serve humanity and to make the world a better place, many scientific findings are being used against human society and man's happiness. The stored atomic bombs have the capability to demolish the entire planet ten times over. There are many lunatics governing the world with the ambition to live long and rule over the world at any price and by any means. Now, if scientists continue these projects of cloning human beings and, in the future, these oppressive rulers take control of this technology then what would happen to the world and its people? (Khorrami 2004: 16)

\section{Analysis}

If the possibility of misusing clones can justify abandoning such a scientific project, then the same must be applied to most other research or projects. For example, the politicians are likely to use atomic technology to produce bombs, so working on nuclear technology must be immoral, but on the contrary we see that, while the possibility for this technology to be misused is very high, there are countries in the world that possess these types of bombs.

Regardless of these facts, all countries are struggling to get this technology in order to guarantee their future since they see that there are concerns with the normal fuels that exist and are used today. Also, there are many other uses for this technology, for example, in medical issues and etc. Therefore, working on this technology is justified and acceptable as a certain right of all countries. If it is so, then the same might be said about cloning. It is likely to be used in wrong ways, but there are also good uses for cloning that must be brought into consideration.

Besides, this possibility has nothing to do with cloning itself and, by its nature, it cannot be considered immoral.

The third point is that cloning is a very expensive and time-consuming process, so it is not economical and reasonable to have mass creation projects through cloning. One may argue that you can get cheaper "slaves" more rapidly from the natural way of producing a human being.

\section{Twelfth: Cloning opposes the principle of end}

The principle of end, introduced by Kant, suggests people to behave towards others in a way that their humanity is an end and not a mere means. 
Since in cloning, the humanity of the cloned person is considered as a means and the purpose behind cloning is simply to create a large number of identical humans to be used during wartime, or for hard labor during periods of peace, or to create a mass group of scientific, political or martial geniuses or to replace the dead child or partner. Therefore, due to this wrong approach towards cloning, it is forbidden (Atrak 2012: 81).

\section{Analysis}

Of course this argument cannot put an absolute ban on cloning. In fact, the opponents who raise this concern have misunderstood what Kant means by this principle since, in cloning, man can be considered as an end. So, the principle of the end only rejects that the cloning that produces men with special talents and abilities to serve for specific goals, for example creating men with strong bodies in order to fight in wars. But, this principle does not reject cloning for producing a sound man with no genetic disease or deficiency, because through producing man in this way, his/her humanity has been brought into attention as an end.

Therefore, for man to be produced as a means or an end, it depends on the intention of the agents performing the cloning.

Moreover, such a problem might happen with natural procreation as well, since sometimes parents procreate to have children as a support for them in their old age, to fulfill their own dreams or to continue their progeny.

\section{Thirteenth: Exploiting women}

One of the moral worries regarding cloning is the possible misuse and exploitation of women for presenting their egg and also to host the embryo. To do cloning, the somatic cell and a woman's egg are required to put the cell in the egg, and then it must be planted in a womb, so for all this to be successful, a woman is needed. Once cloning becomes popular, it is possible, some opponents argue, that due to economic problems and poverty, some women could be sold as slaves to be used in cloning procedures, or they might volunteer themselves. In fact, their need, especially for women from racial or ethnic minorities, prisoners, and those impoverished, could force them to step forward accepting the possible physical and psychological risks. "The process of obtaining these eggs, which is not without risk, would use women's bodies as mere reservoirs of oocytes, instrumentalizing women and undermining their dignity." (Savulescu 2007: 13) 


\section{Analysis}

A. Cloning is an expensive procedure and, at the least, it is unlikely to become widespread to have such consequences as mentioned above.

B. This problem is not in cloning itself and it refers to the wrong way of handling it.

C. By such an objection they cannot abandon all support for cloning. If a woman is ready to give her egg or bear the embryo, then there is no moral problem.

D. So, if an infertile couple wants to clone their own child, it cannot be rejected this way.

E. What is wrong with women being given such a chance to help procreate humans and in response get some money to solve their problems?

F. What is wrong with someone bearing and delivering the baby with another woman raising the child? There are many of these examples in everyday life today.

G. The same is with a surrogate pregnancy that the one who takes care of the baby as its mother is different from the one who bears and delivers it.

The opponents of cloning are very pessimistic towards cloning and this is due to the negative picture which has been created in their minds.

\section{Fourteenth: increasing illicit sexual relations}

Human reproductive cloning damages human dignity and respect in a sense when it is possible for everyone to simply clone and get a child this way, then why would someone attempt to get married and incur more problems through that? The head of the Muslim World League believes that for the same reason, cloning is forbidden (Abdullah Bakr, internet). Cloning will help spread sexual vices on the earth (al-Khadimi 2004: 80). In this claim, the possibility of having children through cloning will lead to reluctance towards marriage. On one hand, there is the sexual desire and lust in human beings and there should be a way for them to meet sexual needs. Therefore, the only way to satisfy these needs is to fall into sexual crimes.

\section{Analysis}

First: This argument is based on two assumptions:

A. The main purpose of getting married is to have a child.

B. With cloning, man does not need to get married. 
It cannot be universally acceptable to say that the goal of human beings getting married is to have children. Rather, we can say that in many cases there are other intentions like falling in love, having sexual or emotional feelings towards someone, or finding pleasure in living with someone. It could be all or some of these or other reasons altogether. These needs are not to be met by having a cloned baby; the couple would still have the needs for each other.

So, man's need for marriage is not solely confined to having a child, instead, there is a need in a normal human being for someone from the opposite sex to have a happy life together. So, if the person is religious, he/ she prefers to get married to meet their sexual, emotional and other needs, regardless of the fact that they can have a child from cloning or not.

Second: It is not reasonable to say people will clone babies to run away from the difficulties of having a family. According to opponents, there will not be a strong emotional relationship between the cloned child and the parents, so why would they decide to bring a child into the world and take the responsibility for the child by cloning?

Third: If they get married, it might be much easier to raise a child since the couple can cooperate with each other and share the responsibility of taking care of the baby. However, if a man or woman wants to shoulder all the responsibilities alone, he/she will have a very difficult task ahead of them, especially in societies where both men and women work to earn money. Raising a child together is easier so it is not logical to say that in order to run away from responsibilities they choose not to get married and raise a cloned baby.

Fourth: The question is: how can a person who is afraid of responsibility towards a family, wish to have a child and be responsible for it? Is it not difficult to raise a child, especially for a woman who wants to have her cloned cell or that of her husband's in her womb? In this situation, a woman must tolerate the difficulty of the cloning process and the expenses of paying for it, while having a child through sexual intercourse has no serious cost involved.

\section{Conclusion:}

According to what we have discussed, it can be understood that the ethical objections given against human reproductive cloning, considering it as violation of human dignity can be rejected by the proponents. A majority of these objections are influenced by science fiction and the objections are not 
strong enough to stand against justification. Of course, it does not mean that cloning a human being is certainly in compliance with human dignity, so there might be cases of cloning to hurt human dignity, but there also could be cases of cloning without having such a consequence. The points mentioned below are the different interpretations discussed in this article about the claim that human reproductive cloning violates man's dignity:

1. Man's dignity is in the specific way of procreation.

2. Man's dignity is bound to keep his genetic structure.

3. To produce man as a bank of organs opposes his/her dignity.

4. No one has the right to make decisions for man and to choose his/ /her attributes.

5. The cloned man will be underestimated as a product.

6. Knowing that the child has only one genetic parent will cause humiliation.

7. Cloning turns man into a laboratory mouse and hurts his/her dignity.

8. Through cloning they impose one's identity on another person and this hurts his/her dignity.

9. Cloning hurts collective dignity of all humanity.

10. Practicing cloning violates man's freedom and the right to choose.

11. Cloning leads to misusing cloned people.

12. Cloning opposes the principle of end.

13. Cloning is a way of exploiting women.

14. Cloning increases illicit sexual relations.

Received: February $14^{\text {th }}, 2017$

Accepted: May $8^{\text {th }}, 2017$

\section{References}

The Quran

Abdullah Bakr, A. "Al-Istinsakh al-bashari wa Hukmuhu fi Sharia al-Islamiyah" (Internet), availeble on http://www.rabitat-alwaha.net/moltaqa/showthread. php?t=79666 (visited on August 11 $1^{\text {th }}$ 2015).

Atrak, Hosein (2012), "Naghdi Bar Dalaele Akhlaghie Mokhalefane Shabihsaziye Ensani”, Akhlagh Dar Omur Wa Fanawari 7 (3): 1-11.

Ayatee, Seyyed Mohammad Reza \& Ameriniya, Mohammad Baqer (2008), "Naghd wa Barresie Didgahhaye Ahle Sonnat Dar Shabihsaziye Ensanee", Faslnamehe Feqh wa Mabanie Hoghugh 4 (4): 157-173. 
Al-Barzanji, Munthir Tayyib \& Al-Adili, Shakir Ghani (2001), Amaliyatu atfal al-anabib wa al-istinsakh al-bashariyya fi manzur al-sharia al-islamiyah, Beirut, Muassasa ar-risala li at-tiba'a wa an-nashr wa at-tauzi'.

Al-khadimi, Nuruddin ibn Mukhtar (2004), Al-Istinsakh fi zau' al-usul wa al-qavaid wa al-maqasid al-sharia, Damascus: Dar Wahy al-ghalam.

Birnbacher, Dieter (2005), "Human Cloning and Human Dignity", Reproductive BioMedicine Online 10 (1): 50-55.

Cogan, R. (1998), Critical Thinking, New York, University Press of America.

Eslami, Seyyed Hasan (2006), "Chaleshhaye akhlaqiye shabihsaziye ensani”, Akhlaq 1 (4): 7-56.

Fadhlullah, Muhammad Husein \& Rizq, Hani \& Zuhayli, Wahba \& al-Awa, Adil \& Ulwani, Abdul-Wahid \& Sabi'i, Adnan \& Salim, Muhammad Adnan (1997), al-Istinsakh jadal al-ilm wa ad-din wa al-akhlaq, Damascus: Dar al-fikr.

Shalev, Carmel (2002), "Human Cloning and Human Rights: A Commentary", Health and Human Rights 6 (1).

Kfoury, Charlotte (2007), "Therapeutic Cloning: Promises and Issues", McGill Journal of Medicine 10 (2): 112-120.

Khabir, Amal \& Talibi, Ammar (2012), al-Ishkaliyya al-akhlaqiyya li al-istinsakh, Algeria, Fakulty of Humanity, University of Algeria.

Khorrami, Jawad (2004), "Shabihsaziye ensan, payamadha wa aksolamalha", Mobaleghan 13 (3): 161-173.

Lin, Albert, "Human Cloning: What Will We Become?" (Internet), available on: http://web.stanford.edu/ cbross/albertrpdarft.html (visited on Decemer $2^{\text {nd }}$ 2016).

Lopez, Emilia (2004), Three Types of Cloning and the Necessity to Regulate, University of California at Santa Cruz.

Ma, Hongbao (2004), "Technique of Animal Clone", Nature and Science 2 (1): 29-35.

McGrath, James \& Solter, Davor (1984), "Completion of Mouse Embryogenesis Requires Both the Maternal and Paternal Genomes", Cell 37: 179-183.

Mohagheghe Damaad, Mostafa (2007), "Shabihsazi az manzare feqh wa akhlagh", Faslnameze Hoquqe pezeshki 1 (1).

Mowahhed, Mohammad Ali (2002), Dar hawaye hagh wa edaalat, Tehran, Nashre Karnameh.

Noormohammadi, Gholam Reza (2005), Shabihsaziye ensan: bimha wa omidha, Tehran, Daftare Nashre ma'aref.

Owdatullah, Riyad Ahmad (2003), al-Istinsakh fi mizan al-Islam, Omman, Daru Usamah.

Al-Qaradawi, Yusuf, "al-Istinsakh al-bashari marfuzun diniyan akhlaqiyan" (Internet), available on:

http://www.muslimworldleague.org/paper/1777/articles/p6-a1.htm (visited on August 23 $3^{\text {rd } 2016) . ~}$

Ranjbariyan, Amir Hosein \& Seyf, Zahra (2009), "Chaleshhaye hoquqe bashariye shabihsaziye ensan", Hoquq 39 (1): 129-156. 
Savulescu, Julian (2007), Ethics of Stem Cell and Cloning Research, University of Oxford.

Strong, Carson (2005), “The Ethics of Human Reproductive Cloning", Reproductive BioMedicine 10 (1): 45-49.

Shuster, Evelyne (1997), "Fifty Years Later: The Significance of the Nuremberg Code", The New England Journal of Medicine 337 (20): 1436-1440.

Spemann, Hans (1938), Embryonic Development and Induction, New Haven, Connecticut, Yale University Press.

Vajta, Gabor \& Gjerris, Mickey (2006), "Science and Technology of Farm Animal Cloning: State of the Art", Animal reproduction science 92 (3-4): 211-230. 